\title{
Power and Dependency in an Interdependent World: A Guide to Understanding the Contemporary Global Crisis
}

\author{
GARY GEREFFI \\ Duke University, Durham, North Carolina, USA
}

Perceptions of a GLOBAL GRISIS have been rampant for over a decade. Third world nations fear their development prospects are being undermined by a series of devastating external shocks. Unprecedentedly high levels of foreign debt service, coupled with climbing interest rates and falling export revenues, have forced many developing countries to cut imports, restrict public-sector spending, curtail economic growth, and confront spiraling unemployment. The economies of the third world grew by an average of just six-tenths of 1 percent in 1981, and the figures were worse for 1982. Per capita income fell for the first time in twenty years. Even OPEC members, who gained most from increased oil prices in the 1970s, are concerned that lower prices and falling oil revenues may jeopardize their ability to repay extensive loans some of them acquired from Western banks at the height of the oil boom.

In the developed countries as well there has been a contraction of trade and investment activities, and slow growth has produced new sentiment for protectionism and other retaliatory measures. Immigration is increasing and becoming more conflictive. Bankruptcies are common. International financial institutions and the world's leading commercial banks have already agreed on emergency measures to avoid immediate collapse if major third world borrowers were to declare themselves insolvent and unable to service their debts.

While the scope of the contemporary crisis is global in that all nations are affected by it, the burden of suffering is unevenly distributed. Some countries have even appeared to reap benefits. Progress was most evident among the oilexporting nations who sought to transform their economies quickly through huge imports and investments. Despite the windfall in revenues made possible by skyrockating oil prices in the 1970s, today oil producers such as Mexico, Venezuela, Nigeria, and Indonesia are experiencing severe slumps. The current crisis has been felt in different ways throughout the third world. Africa has been hurt most by low prices for its commodity exports and the shortage of foreign aid. In Latin America big borrowers have been caught in a debt trap, squeezed by high interest rates and increasingly scarce foreign credit. And 
Asia, though least affected by the recession so far, is rapidly losing markets for its manufactured exports.

Although the major industrial countries also experienced economic downturns in the $1970 \mathrm{~s}$, some of the worst effects were moderated as oil prices began to fall. Of greater concern, especially in the United States, were the challenges to international competitiveness brought about by a rapidly changing world marketplace. One indicator of this was the decline in labor productivity within the United States, which went from an annual rate of around 3.5 percent in 1965 to a rate of less than 1 percent in the $1973-1979$ period; at the end of the decade US productivity growth came to a virtual halt. In comparative terms, the US economy appears to have been outperformed in recent decades by both the Europeans and the Japanese. Between 1960 and 1980 Japan's labor productivity in manufacturing increased approximately sixfold and West Germany's multiplied some two and a half times, while that of the United States rose by only 75 percent (Committee for Economic Development, 1983). Relative US decline shows up in other ways: its labor force has been less flexible, its job creation less effective, its shift from obsolescent into high technology industries less swift and sure, its per capita GNP less, and its standard of living lower than its main competitors in Europe and Japan (Magaziner and Reich, 1982).

How can we explain these transformations? Is the contemporary global crisis a product of structured inequalities and exploitation in the international system, or is it instead caused by a failure to allow basically sound market forces to operate freely? Is the United States beginning a long irreversible decline in the world economy, or are the established industrial powers merely converging toward common patterns and levels of development? Do the nations of the third world have the resources and capability to resolve their current economic plight on their own, or will their future be determined by the decisions made in the business and political capitals of the developed countries?

The argument advanced in this paper can be summarized as follows. The rapid growth of the world economy in the 1950s and 1960s occurred during a period of United States hegemony, in which the unity of the world market was rooted in the transnational expansion of trade and investment relationships. The global crisis that emerged in the early 1970 s reflects a series of structural transformations or dislocations caused, at least in part, by the very internationalization of capital that sustained the prior postwar prosperity. The economic prodominance of the United States has been eroded in the past decade by challenges coming from other advanced capitalist nations (particularly Japan and West Germany), and by the establishment of profitable and efficient manufacturing plants in a small number of "newly industrializing" third world nations, some of which export almost exclusively to the U.S. market. The strength of these competitors is a direct outgrowth of U.S. success in revitalizing a world capitalist order after World War II through massive transfers of capital in the form of foreign aid, foreign direct investment, and 
foreign loans, and by promoting the liberalization of international trade. The instability caused by the recent decline of U.S. hegemony has been exacerbated by the OPEC oil cartel, which led to a strengthening during the 1970s of the tendency toward global stagnation, inflation, and speculative pressures on international money and commodity markets.

The current crisis is a crisis of transition. It does not portend, as some would have it, the demise of the capitalist world economy. The United States, although now less dynamic than some of its revals, still represents the center of gravity of an increasingly integrated world economy. The key agent in the international spread of technology, new commodities, and new forms for organizing production is the transnational corporation. The global expansion of these corporations has had both a standardizing and a differentiating effect: it has led to a geographically broader yet more integrated pattern of capitalist production worldwide; and it has multiplied the number of national and institutional actors with a stake in the existing system. The new international division of labor that is emerging remains hierarchically structured, despite the fact that the relative position of individual countries in the hierarchy may change. The perspective on the global crisis presented in this paper seeks to highlight both the stability of fundamental power relationships in the capitalist world economy, as well as the shifting structures of opportunities and constraints within which national development choices are made.

\section{Power and Dependency Relations in the Global System}

To some sociologists the world is unified in the minimal sense that "to an increasing degree, the life of the individual anywhere is affected by events and processes everywhere" (Moore, 1966: 481). A "global sociology" derived from this view would see the world as a singular system whose defining feature is a growing interconnectedness between all societies. Data from the postwar period indeed showed that the world had entered a new and unprecedented era of interconnectedness. Trade among nation-states increased tenfold between 1938 and 1969, direct capital investment abroad by United States firms grew about eightfold from the end of World War II to 1971, the volume of foreign mail sent and received increased almost seven times between 1938 and 1970, the total of international telephone and telegraph exchanges doubled at least every decade, the number of university-level students studying abroad was in excess of 7 percent a year, and international tourist travel grew at nearly 9 percent annually. International governmental and nongovernmental organizations also flourished. In the United Nations, for example, the rate of membership increase from 1945 to 1970 was just under 4 percent per annum, for UNESCO it was 6.4 percent, and for specialized organizations like GATT it was over 10 percent (Inkeles, 1975: 477-479).

As an analytical tool for understanding the structure and dynamics of the modern world system, however, interconnectedness is a very weak notion; it says nothing about the importance of the relationship to the participating par- 
ties. Interdependence is a more meaningful concept since it implies relations that would be mutually costly to break (Baldwin, 1980; Waltz, 1970). To take the example of world trade, countries are mutually dependent (or interdependent) if they rely on each other for goods and services that are relatively vital and cannot easily be produced at home. Interdependence involves a situation, then, in which the opportunity costs of autonomy (in this case, foregoing trade) are high.

Interdependence alone is not sufficiently precise to allow us to sort out the complexities of contemporary international relations, however, and in some cases it can even be misleading. The idea of interdependence minimizes the inequalities of national capability and suggests that all countries are similarly committed to the present world order. Furthermore, it does not address the question of whether relationships between nations are symmetrical or asymmetrical nor does it identify the scope and domain of these relationships.

Where disparities among countries are great, the largest and most developed need worry least about the bothersome activities of others. All of the parties may be vulnerable, but not all are vulnerable to the same extent. When exchanges vital to one partner are of minor significance for a second, the situation of the former is more appropriately described as one of dependency rather than interdependence. A couple of illustrations may help clarify this point. If country A has good coking coal while country B has iron ore, and each supplies the other with what it is lacking to make their own steel, they are interdependent in the steel-making process. If nation $\mathrm{C}$ sends textiles to the United States, and in return receives American grain and computers, the matter appears in quite a different light. It would be relatively easy for the United States to substitute for or do without foreign textiles, whereas its trading partner might find an interruption in its food or sophisticated machinery imports devastating. There is plenty of evidence of the pervasive dependency of the overwhelming majority of third world nations on advanced countries for investment capital, loans, scientific knowledge of all sorts, technical and organizational skills, finished industrial products, and diverse export markets (see Brandt et al., 1980). The basis for asymmetrical and multifaceted relationships of dependency that subordinate peripheral countries to center nations thus is present.

What about the obverse of this situation-the so-called "strategic dependency" of the core powers on foreign sources of supply, particularly third world regions, for critical minerals, cheap labor, and large markets (see Muñoz, 1981)? If the classical international division of labor between advanced exporters of manufactures and underdeveloped exporters of raw materials no longer exists, does this give the concept of interdependence renewed salience? One fact is incontrovertible: the new international division of labor integrates the capitalist world economy to a hitherto unimagined degree. For the first time in history, principally through the operations of transnational corporations (TNCs), there is a single global market for production, labor, financing, and sales of goods and services that effectively encompasses both ad- 
vanced industrial countries and underdeveloped nations. The production process increasingly ignores national frontiers; a watch or a car or even a shirt may include components from widely scattered industrial sites around the globe. The emergence of export-processing zones in the third world permit TNGs to set up industrial enclaves where cheap labor is abundant (Fröbel, Heinrichs, and Kreye, 1978). Global marketing strategies are designed, often with the help of cultural anthropology, to retail old needs to new customers and to create new needs for old customers. Finally, TNCs are in a unique position to play the world capital and currency markets to finance this internationalized system of production, frequently from local resources.

What looks like a thickening web of economic interdependence obscures what may be best understood as a compound of power and dependency relations. The difference is more than just semantic because if the world system is indeed structured in a hierarchical and asymmetrical way, as both dependency and world systems theorists posit, one should expect to find consistent net advantages accruing to the most powerful actors in the system-i.e., the core countries and the TNCs usually headquartered there (see Gereffi, 1983; Evans, 1979; Wallerstein, 1974, 1979). A close analysis of each aspect of the strategic dependency of the centers reveals that dominant nations and TNCs have a variety of power resources at their disposal that reduces their vulnerability and ensures their gains from this form of interdependence.

A good deal of the world's exportable reserves of strategic minerals (e.g., oil, bauxite, copper, manganese, cobalt) are found in the third world, and this obviously causes considerable concern on the part of developed country governments. Reliance on raw material imports at a particular time, however, does not necessarily mean core nations have no other options. The primary goal of the centers is to preserve access to cheap foreign raw materials. Thus the strategic dependency of any core country arises from the physical absence of certain critical minerals and/or the existence of uneconomic conditions for the exploitation of available materials (Muñoz, 1981: 5). The United States, of course, enjoys an abundance of natural resources that helps to buffer it from the threat of acute shortages. But raw material scarcity is a perennial problem in other center countries such as Japan, Switzerland, and to a lesser degree West Germany. How do these advanced industrial nations cope with the critical minerals aspect of strategic dependency?

First, one needs to realize that the reliability of access to raw materials is what counts, not just their possession. In this sense the fact that a large share of the strategic minerals consumed in the centers comes from politically "safe" nations such as Canada, Australia, and South Africa lessens much of the uncertainty surrounding raw material supply. Secondly, foreign economic assistance often is used as a tool of the centers to gain preferential access to the critical minerals in the third world. In order to assure that vital natural resources will be available, the United States channels economic and military aid to Latin America and the Caribbean region, West Germany and other European powers extend their largesse to the resource-rich nations of Africa 
and Asia, while Japan has targeted the South Seas area and increasingly Latin America for economic assistance. As the problem of resources and energy becomes more serious throughout the world, these traditional spheres of influence are likely to be eroded by more intense competition among the center nations for access to the best endowed suppliers. A third and ultimately perhaps the most significant means employed by advanced countries to offset natural resource dependency are technological advances in the recovery, use, and substitution of materials currently in short supply. ${ }^{1}$

Strategic dependency is by no means confined to state-to-state relations; it also denotes a situation in which the international segment of center nations (that sector associated with TNCs) depends for its continued prosperity upon access to natural resources, labor, and markets in the third world. The cheap labor component of strategic dependency embodied in the exodus of TNCs to low-wage areas in reality is a low-risk venture that provides host nations with very little bargaining power, however. Because their labor-intensive operations in Taiwan, Singapore, Hong Kong, the Philippines, and Mexico usually involve small amounts of fixed capital, the TNCs can easily move elsewhere if pressured. The high mobility of these firms is their best defense against escalating local demands.

These overseas production platforms are nonetheless very profitable for the largest global corporations which now have, on average, 33 percent of their net assets, 40 percent of their sales, 46 percent of their work force, and 53 percent of their net earnings outside their "home" countries (UNCTC, 1983: 48). While nearly three-quarters of the world stock of foreign direct investment is concentrated in the advanced industrial nations, the third world accounts for a disproportionate share (over one-half) of all foreign earnings. The overall rate of return for US direct investment abroad in 1981 was 11.5 percent for developed countries compared to 22.5 percent for underdeveloped nations, thus highlighting the greater profitability of third world areas (U.S. Department of Commerce, 1982: 17).

Overseas income is crucial to transnational banking institutions as well. Whereas foreign loans to developing countries stood at $\$ 90$ billion in 1973 , by 1979 they had climbed to over $\$ 300$ billion and in 1982 they surged to more than $\$ 500$ billion. The largest US banks now earn the bulk of their profits on loans made outside the United States, particularly in Latin America. In 1971 only 23 percent of the total income for the twelve biggest US banks originated in their foreign branches; by 1975, overseas profits of these banks had soared to 63 percent of the total (Wachtel, 1977: 9). Chase Manhattan Bank, for example, classified 48 percent of its assets as international in 1976 but it attributed 78 percent of its earnings to those assets. Citicorp's loans to Latin America represented only 6 percent of its assets yet produced 20 percent of its earnings (Lissakers, 1983: 162).

Foreign manufacturing subsidiaries give TNCs far better access to the domestic markets of host nations than would be achieved merely by exporting from the home country. In 1977 the aggregate sales of the overseas subsidiaries 
of US manufacturing TNCs were almost $\$ 300$ million, or about three times US manufacturing exports in that year. This trend is most pronounced in Latin America where local sales of US manufacturing affiliates between 1966 and 1976 consistently remained between 90 and 95 percent of total sales (Muñoz, 1981: 15). Much of what passes for international trade in fact is internalized by TNCs in intra-firm transactions-i.e., trade between affiliates of a single global company. A sample of more than 300 of the world's largest industrial enterprises for 1977 showed that one-third of all parent company exports consisted of intra-firm sales ${ }^{2}$ (UNCTC, 1983: 160). Another study concludes that just under half of all US imports and a similar proportion of US exports are intra-firm in the sense of taking place between parties related by ownership or subcontracting ties (Helleiner, 1981: 10).

What this brief sketch of the new international division of labor indicates, I believe, is a need to reconceptualize the global context. The center and peripheral countries of the world system are not just interconnected in various ways, nor are contemporary international relations primarily characterized by symmetrical ties of interdependence between relative equals in terms of national power and economic resources. The modern world system is singular but far from homogeneous. It has three principal defining features: a predominance of capitalist relations of production, a multi-tiered hierarchy of nations, and asymmetric relationships of exchange between countries occupying different structural positions in the international economic system.

The capitalist basis of the modern world system has been amply documented and discussed by Wallerstein $(1974,1979)$ and others. The world system approach has been far more ambiguous, however, concerning the nature and number of hierarchical divisions in the world economy. Originally a tripartite division between core, semiperiphery, and periphery was proposed. Although the notion of an identifiable semiperiphery has given rise to some useful comparative insights (e.g., Gereffi and Evans, 1981), what is crucial is not the number of layers but rather the idea of nations occupying structurally similar positions in a global system. One recent and very illuminating study using blockmodel and multiple network techniques to identify "structurally equivalent" blocks of countries in terms of their international trading patterns finds a four-tiered division rather than the tripartite split usually referred to in the world system literature ${ }^{3}$ (Nemeth and Smith, 1983). Each country's structural position in the world economy implies a distinct role in the overall division of labor that affects its prospects for national development.

Asymmetrical relationships in the world system imply dependency and vulnerability stemming from disparities of economic and political power. This goes beyond the notion of complementary roles since these disparities are endemic to the very structure of the system. Despite persistent asymmetries, however, it is important to recognize that capitalist expansion affects each society differently. Natural attributes such as geographical location and resource endowments, along with institutional, political, and cultural factors, inevitably leave their unique imprint on national development. These internal 
structures of developing countries help explain varied patterns of linkage to the international system as well as diverse responses to dependency itself. Thus, the inward-oriented import substitution model of development followed by many of the Latin American countries contrasts sharply with the outwardoriented manufactured export model that has proven so successful for the East Asian nations. Similarly, third world countries have made different choices about their openness to direct foreign investment, foreign aid, and the levels of external debt they are willing to assume.

In the remainder of this paper, I will try to situate the contemporary global crisis in the context of the growing internationalization of the center countries and the various forms of dependency that have shaped and constrained development options in the third world. My fundamental argument will be that the duration and effects of the crisis are mainly determined by the goals and interests of the dominant actors in the system: the core nations and the TNCs. Third world nations can do little to influence the main causes of - or solutions to-their economic problems.

\section{The Growing Internationalization of the Center Countries}

The United States, the leading industrial powers in Western Europe, and Japan have become more and more integrated into the global economy in the past decade. This makes proposed solutions to the contemporary crisis more complex and difficult to implement; it also increases the third world's vulnerability to the world recession. Commodity prices are at their lowest level in thirty years, ${ }^{4}$ high interest rates have led to a shortage of foreign credit, ${ }^{5}$ the aid flow to poor countries has begun to fall steadily, there is growing trade protectionism, and revenues from tourism have sharply declined. Only the recovery of the economies of the advanced industrial nations, many believe, will eventually revive demand for third world exports and free resources that can be channeled to developing countries. The validity of this assertion can be assessed by examining two related issues: the interdependence of the core nations and the persistence of dependency in the third world. Both interdependence and dependency have implications for how and at what cost the global crisis might be resolved.

During most of the post-World War II period, international trade maintained an impressive 8 percent growth rate. World trade has declined for the past two years, however, the longest slump since 1945. Despite this recent downturn, the overall increase in the importance of international trade contributed to a major realignment of the center countries in the world economy. Between 1960 and 1980 the United States experienced the lowest productivity growth of any advanced industrial nation. During this same period the US economy, which had always been relatively autarkic, became much more internationalized. The share of imports in final sales of goods in the United States more than doubled between 1970 and 1979, from 9 percent to 21 percent. ${ }^{6}$ International competition affected US export performance as well. 
Manufactured exports from the United States in 1962 accounted for 14 percent of developed country imports and 34 percent of less-developed country imports; by 1979 the market share of US manufactured exports had fallen to 10 percent and 26 percent, respectively. The shares of both Japanese and West German exports to these areas in turn have risen (Evans, 1982: Table 2).

The percentage of world resources controlled by the United States is shrinking and the country may also be losing its technological edge. The US share of total capital resources in a sample of 34 developed and less-developed countries fell from 42 percent at the beginning of the 1960s to 33 percent by 1975 while Japan's share rose from 7 percent to 15 percent; in the same sample the United States ranked third from the bottom in terms of growth of skilled labor endowments. Between 1965 and 1977 the number of scientists and engineers per 10,000 in the US labor force dropped by 10 percent while it more than doubled in Japan and almost doubled in West Germany. In addition, the latter two countries have begun to pull even with the United States in terms of the percentage of GNP devoted to research and development in industry (Evans, 1982: 3-5).

Overall, there has been a decline in the position of the US manufacturing sector relative to industrial development in the rest of the world. Most dramatic is the evidence on eroding market shares in a variety of industries at home and abroad. In 1960 US manufacturers held a dominant position (well over 90 percent of sales) in all the major industries in the United States. By 1979 levels of domestic control had fallen in every industry, the decline being most severe in consumer electronics ( 49 percent local share), textile machinery (54 percent), footwear (63 percent), machine tools (75 percent), and automobiles (79 percent). The US position in the world market has also been reduced in many traditional strongholds like motor vehicles, machinery, plastics, and telecommunications (see Table 1).

The United States has long been recognized as the preeminent foreign investor in the world. With $\$ 227$ billion in direct investment abroad at the end of 1981, the United States accounts for approximately one-half of the total flow of direct investment assets. Less well known is the fact that the United States has recently passed Canada as the number one host country for foreign capital. Because US-based enterprises were involved in international investment activity very early in the post-World War II era, US investment overseas is still two-and-a-half times greater than foreign investment in the United States (see Table 2). During the past decade, however, the rate of investment coming into the United States from foreign sources has been far higher than that going out of the country. There has been almost a sevenfold increase in direct foreign investment in the United States since 1970, with spectacular increments of 26 percent in 1980 and a record 31 percent in 1981. US investment abroad went up 15 percent in 1980 and only 5 percent in 1981, the lowest rate of increase in the postwar period (see Table 2). The three main foreign investors in the United States are the Netherlands (22 percent of the 1981 total), the United Kingdom (17 percent), and Canada (14 percent). 
Table 1

Trends in the Decline of U.S. Industry

\begin{tabular}{|c|c|c|c|}
\hline \multirow[b]{2}{*}{ Industry ${ }^{1}$} & \multicolumn{3}{|c|}{$\begin{array}{l}\text { U.S. Share of the United States Marke } \\
\text { (percentage of total industry sales) }\end{array}$} \\
\hline & 1960 & 1970 & 1979 \\
\hline Autos & 96 & 83 & 79 \\
\hline Steel & 96 & 86 & 86 \\
\hline Apparel & 98 & 95 & 90 \\
\hline Electrical components & 100 & 94 & 80 \\
\hline Farm machinery & 93 & 92 & 85 \\
\hline Industrial inorganic chemicals & 98 & 92 & 81 \\
\hline Consumer electronics & 94 & 68 & 49 \\
\hline Footwear & 98 & 85 & 63 \\
\hline Metal-cutting machine tools & 97 & 89 & 74 \\
\hline Food processing machinery & 97 & 92 & 81 \\
\hline Metal-forming machine tools & 97 & 93 & 75 \\
\hline Textile machinery & 93 & 67 & 54 \\
\hline \multirow[t]{2}{*}{ Calculating and adding machines } & 95 & 64 & 57 \\
\hline & \multicolumn{3}{|c|}{$\begin{array}{l}\text { U.S. Share of the World Market } \\
\text { (percentage of world exports) }\end{array}$} \\
\hline Industry ${ }^{2}$ & 1962 & 1970 & 1979 \\
\hline Motor vehicles & 23 & 18 & 14 \\
\hline Aircraft & 71 & 66 & 58 \\
\hline Organic chemicals & 20 & 26 & 15 \\
\hline Telecommunications apparatus & 28 & 15 & 14 \\
\hline Plastic materials & 28 & 17 & 13 \\
\hline $\begin{array}{l}\text { Machinery and appliances } \\
\text { (nonelectric) }\end{array}$ & 28 & 24 & 20 \\
\hline Medical and pharmaceutical pro- & & & \\
\hline ducts & 28 & 18 & 17 \\
\hline Metal-working machinery & 32 & 17 & 22 \\
\hline Agricultural machinery & 40 & 30 & 23 \\
\hline Hand or machine tools & 20 & 19 & 14 \\
\hline Textile and leather machinery & 16 & 10 & 7 \\
\hline Railway vehicles & 35 & 18 & 12 \\
\hline Housing fixtures & 23 & 12 & 8 \\
\hline
\end{tabular}

${ }^{1}$ Ranked by total sales of industry.

${ }^{2}$ Ranked by size of U.S. exports.

Source: Business Week, 1980: 60.

The biggest benefactor of the postwar era of free trade has been Japan, today one of the United States' foremost competitors in domestic and overseas markets. Japan's great industrial boom of the 1960s and 1970s depended heavily on expanding world trade. The export triumphs of the Japanese were won with excellent products, but at the expense of jobs and profits in the countries that bought the Japanese goods. In 1981, for example, Japan exported nearly $\$ 30$ billion more worth of goods to the United States and Western 
Table 2

Foreign Direct Investment and the United States, 1950-1981

\begin{tabular}{ccc} 
Year & \multicolumn{3}{c}{$\begin{array}{c}\text { Foreign Direct Investment } \\
\text { in the United States }\end{array}$} \\
& U.S. Direct Investment Abroad $\begin{array}{c}\text { Billions of dollars } \\
1950\end{array} \mathbf{c}^{2}$ & 3 \\
1955 & 19 & 5 \\
1960 & 32 & 7 \\
1965 & 50 & 9 \\
1970 & 76 & 13 \\
1975 & 124 & 27 \\
1979 & 150 & 35 \\
1980 & 193 & 54 \\
1981 & 216 & 68 \\
\hline
\end{tabular}

Source: U.S. Department of Commerce, Survey of Current Business, various issues.

Europe than it bought from thes areas; over half that favorable balance of trade was with the United States. A good portion of the Japanese goods were competitive with local manufactures, thus fueling protectionist sentiments calling for an all-out trade offensive against Japan (see Newsweek, 1983a).

If the era of free trade is waning, then the Japanese can no longer go on doing business in the way that has made them so successful. There are, in fact, signs that their economy may be headed for trouble (Gall, 1983). Japan's exports were down by more than 13 percent for the second half of 1982, the biggest peacetime drop since the 1938-1941 period. Excess capacity has accumulated in many Japanese industries such as steel, autos, aluminum, plywood, petrochemicals, and shipbuilding. Increasingly Japanese firms must begin manufacturing abroad, which means exporting capital and technology rather than physical products. ${ }^{7}$ Japan's critical lack of raw materials is also beginning to pinch. US-made aluminum and ethylene, for example, can now be purchased for 40 percent of the Japanese domestic price in large part because the cost of electricity in the United States is one-fourth as much as in Japan. Manufacturing investment as a share of GNP shrank from 9.4 percent in 1970 to 6.1 percent in 1980 (still well above the US rate of 4 percent). Finally, while economic growth has slowed down, public spending in Japan continues to grow. The United States' supply-side deficits pale into insignificance compared to Japan's 1983 federal deficit of $\$ 70$ billion (33 percent of the entire federal budget, 6.4 percent of the GNP) -all this with a minimal outlay for national defense.

Japan's most serious economic challenge in the 1980s is likely to come from its neighbors in East Asia, the so-called "gang of four": Taiwan, South Korea, Hong Kong, and Singapore. During the 1970s these four economies grew at an annual average rate of more than 9 percent, compared to yearly growth rates of 6 percent for Japan and just 3 percent for the United States. 
Economists predict that in the decade of the 1980s Taiwan, South Korea, Hong Kong, and Singapore will continue to increase the size of their economies by 7 to 9 percent a year, while the annual gains in Japan's more mature industrial structure will be around 4 percent (Lohr, 1982). What is most impressive about the four "new Japans" is that, like Japan itself, they are successfully moving out of labor-intensive industries, such as textiles, footwear, and simple electronics items, into higher-technology fields. Manufactured exports have been the vehicle for this rapid progress. In 1979 Taiwan, South Korea, Hong Kong, and Singapore together generated more than 60 percent of all third world exports of manufactures ${ }^{8}$ (Fishlow, Carrière, and Sekiguchi, 1981: 23). The common Achilles heel of the East Asian nations, though, is a lack of natural resources, especially oil. In the absence of a sudden surge in world economic prosperity, heightened trade tensions and more protectionism are likely. The United States is well positioned to extract major concessions, if it wants to. The US is East Asia's leading trading partner-with a trade deficit that could rise to as much as $\$ 50$ billion with Japan alone in 1983-as well as a primary supplier of raw materials to the region.

Although West Germany is undoubtedly the largest economy in Western Europe, the one that has most effectively oriented its growth in terms of current world realities is Switzerland. In the late 1970s Switzerland was one of the richest nations in the world with a per capita GNP of nearly $\$ 14,000$, it exported close to 50 percent of its total goods and services, its current account surplus surpassed that of West Germany and was second only to Japan's, its official unemployment figures are lower than those of all other advanced industrial countries, and its inflation rate in 1978 was just 1 percent (Katzenstein, 1980: 507-508). Switzerland's stunning economic performance is based on a strategy of export promotion whose impetus overwhelmingly resides in the private sector. The Swiss TNCs, and especially the six largest ones (Nestlé, Ciba-Geigy, Hoffmann-LaRoche, Alesuisse, Brown Boveri, and Sandoz), also tend to be more internationalized in their production than the firms in any other country. Their overseas operations account for 71 to 95 percent of their employees and 63 to 96 percent of their sales (Katzenstein, 1980: 520). Switzerland's well known frugality when it comes to questions of public welfare spending has been facilitated by the importation of a foreign proletariat that acts as a buffer against the dangers of unemployment. ${ }^{9}$

The global crisis has weakened the economies of the center countries, but it certainly has not crippled them. The most notable decline has been in the economic performance of the United States. In large measure, though, the United States has willingly allowed this to happen. Any attempt to counter Japan's economic clout by banning Japanese imports and using threats to pry open the Japanese market to US products would probably be self-defeating. It could lead to protectionist warfare and an eventual strangulation of world trade. At present, one out of every five jobs in US manufacturing depends on exports and 33 percent of all American farm produce is shipped overseas (Newsweek, 1983a: 26). The United States, Western Europe, and Japan all 
have a tremendous stake in the internationalization of production and an open trading system. A globally integrated world economy is vital, then, to the continuing strength of the center countries.

A protectionist response by the core powers is even less justified vis-à-vis successful third world exporters like the East Asian "gang of four." Of total world exports, 70 percent originate from the advanced industrial countries. Manufactured exports from the third world represent only 5 percent of total world exports and 18 percent of all third world exports (Fishlow, Carrière, and Sekiguchi, 1981: 14, 23). In fact, the best third world customers for center country products have been those with the most rapidly growing exports. The non-OPEC developing nations import more than twice the value of manufactures that they export to the developed countries; the absolute difference jumped from $\$ 25$ billion in 1973 to $\$ 69$ billion in 1979. Japan's surplus from its industrial trade with the third world was a whopping $\$ 36$ billion in 1979 , or about half its world surplus in manufactures. The export-import ratio of trade in manufactured goods with the third world in 1979 was 7 to 1 for Japan, 4 to 1 for Europe, and 2 to 1 for North America (Fishlow, Carrière, and Sekiguchi, 1981: 26-28).

The center countries profit handsomely from their trade and investment ties with the third world. In many cases these international transactions are much more lucrative than similar business dealings at home. It remains to be seen how the global economy looks from the perspective of the periphery-a view from the bottom up.

\section{Third World Dependency and the World Recession}

The increased internationalization of the center countries has made them more interdependent on one another and indeed more sensitive to fluctuations in the world economy generally. The great advantage of the center countries, however, is that they have the capital, technology, and markets needed for their development process to be relatively self-sustaining. This is not true of most of the third world. The development of peripheral nations usually requires critical external complements. The more extensive this external reliance-on imported goods, foreign direct investment, foreign loans, export markets for commodities or manufactured items, etc. - the more dependent the country is. To better appreciate the degree of asymmetry involved in first world-third world relations, it is worthwhile to look more closely at the United States' ties with Latin America, and especially Mexico.

Of all the third world regions, Latin America is by far the most important to the United States. Overall trade in manufactures between the United States and Latin America grew nearly fivefold during the 1970s. By 1979 US manufactured exports to Latin America totaled $\$ 21.8$ billion (19 percent of US manufactured exports worldwide), while Latin America's manufactured exports to the United States stood at $\$ 4.5$ billion (24 percent of Latin America's global total). The United States thus enjoyed a positive trade balance in 
manufactures with Latin America of $\$ 17.3$ billion in 1979. This was more than two-fifths of Latin America's negative trade balance in industrial goods with the entire world. Without the Latin American surplus the United States would have had a negative trade balance in manufactures of almost $\$ 12$ billion in 1979 instead of its positive trade balance of over $\$ 5$ billion (Evans, 1982: Table $5)$.

International capital flows are usually much more asymmetrical than trade flows. Foreign direct investment, portfolio investment, and loans almost always flow from the core to the periphery of the world system. Unlike commodities, flows of capital may also bring external control over the local productive apparatus in host economies. Third world nations are important recipients of foreign direct investment (FDI). ${ }^{10}$ They represent about one-quarter of the inflow of total FDI, but they contribute a full one-half to the outflow of profits and similar payments that go back to the companies from this form of investment. During the end of the $1970 \mathrm{~s}$, a mere half-dozen countries (Argentina, Brazil, Hong Kong, Malaysia, Mexico, and Singapore) consistently held between one-half and three-quarters of all FDI channeled to the third world. As a source of FDI, the third world plays a negligible role, however. Less than 2 percent of all FDI reported in 1978-1980 originated in the developing countries. The United States was the source of approximately half of the total flow, distantly followed by the United Kingdom (14 percent), West Germany (10 percent), and Japan and Canada (6 percent each) (UNCTC, 1983: 17, 19).

If one focuses on US FDI only, one finds that one-quarter of it was located in the third world at the end of 1981. Latin America was the site of 70 percent of total US FDI and of over 80 percent of US manufacturing investments in developing countries. Within Latin America, manufacturing accounted for 41 percent of US direct investments, followed by petroleum (12 percent), trade (11 percent), and banking (10 percent) (U.S. Department of Commerce, 1982: Table 1). It should be pointed out that US manufacturing FDI in Latin America is very diversified, since it was stimulated by import substitution policies aimed at supplying domestic markets. Except for the underrepresentation of non-electrical machinery, the sectoral distribution of Latin American investment closely parallels the distribution of worldwide US FDI in manufactures. ${ }^{11}$

Mexico is in many ways a symbol of the asymmetry of first world-third world relations and of the third world's vulnerability to the world recession. Despite attempts to diversify its trade and investment ties, Mexico remains overwhelmingly dependent on the United States. Three-quarters of its exports and over two-thirds of its imports were carried out with the United States in 1980. While Mexico is the United States' third most important trading partner (after Canada and Japan), the situation looks quite different from north of the border. The United States received 5 percent of its imports from Mexico and sent 6 percent of its exports there in 1980 (Randall, 1981: 49-50). What is a huge proportion of Mexico's trade is thus a small share of US trade. Furthermore, Mexico regularly runs a trade deficit with the United States which stood 
at $\$ 1.6$ billion in 1979 . One of the obvious political implications of this asymmetry is that US domestic economic decisions will affect Mexico much more than Mexico's decisions affect the United States. ${ }^{12}$

Mexico's trade imbalances are compounded by other forms of dependency. Approximately three-quarters of the FDI in Mexico is by US-based firms. (Mexico absorbs about 3 percent of all US direct investment abroad.) US TNCs in Mexico tend to be among the largest firms and they are in the fastest growing industries, such as chemicals, rubber, machinery, metal fabrication, transportation equipment, and food processing (see Gereffi and Evans, 1981). The potential power of TNCs to set guiding policy is increased by the fact that most of these industries are oligopolies in which the conduct of a few big sellers largely determines industry performance. Mexico's reliance on its neighbor to the north also is evident in a different sort of economic activity: tourism. Mexico ranked fourth worldwide in tourist income in 1979 ( $\$ 1.4$ billion) and it has the largest tourist industry in Latin America. In 1980 tourism was expected to net $\$ 1.6$ billion, or 38 percent of Mexico's balance of payments and 6 percent of its GNP (Cobb, 1981: 179). Since 85 percent of Mexico's tourist arrivals come from the United States, continued prosperity in this sector is heavily dependent on the condition of the US economy.

Undocumented workers are one of the most sensitive problems dividing the United States and Mexico. With high levels of unemployment and underemployment (estimated at nearly 70 percent in rural areas) and with demographic patterns projecting a significant labor surplus situation well into the next century, Mexico views the continuing flow of undocumented workers northward as an important safety valve that helps assure its social and political stability. The incentive for these workers is predominantly economic, due to huge real-wage differentials between the United States and Mexico that for many low-skill occupations range between 8:1 and 13:1 (Cornelius, 1981: 108, 115-116). These differentials have widened even more with the recent devaluations of the Mexican peso. Given the losses already suffered by US workers due to the recession in their own country, the mounting pressures on the American side to restrict the flow of undocumented Mexican workers into the United States are taken very seriously indeed by the Mexican government. They further call into question what is already a very uncertain economic forecast for Mexico in the coming years.

The most explosive issue facing Mexico and other third world nations today, however, is "the debt bomb". Over slightly more than a decade the external debt owed by governments and state enterprises in developing countries to foreign creditors has skyrocketed tenfold, from $\$ 64$ billion in 1970 to about $\$ 600$ billion in $1982 .{ }^{13}$ The external debt burden, while a common phenomenon throughout the third world, is particularly acute in Latin America which owes around $\$ 300$ billion or one-half of all developing country external public debt. The amounts owed by the largest third world borrowers in 1983 are staggering: Brazil- $\$ 90$ billion; Mexico- $\$ 83$ billion; Argentina $-\$ 40$ billion; Venezuela $-\$ 32$ billion; Poland $-\$ 24$ billion; Chile- $\$ 21$ 
billion; Nigeria $-\$ 15$ billion; and Peru $-\$ 12$ billion (Newsweek, 1983b: 34-35; New York Times, 1983). This transfer of external financial resources has been described as "the most rapid, most concentrated, most massive flow of investment capital to the Third World in history" (Frieden, 1981: 407).

With the unprecedented expansion of third world external public debt came a significant change in its composition: more and more loans were acquired from private sources, particularly commercial banks active on the Eurocurrency market. In Latin America and elsewhere, the proportion owed to private rather than official creditors rose from less than one-half in 1970 to approximately two-thirds in 1980 (Lewis, 1983: 14; Inter-American Dialogue, 1983: 15). This new mix produced a more onerous debt structure for two reasons: it shortened the average maturities of the external public debt and its cost depended on floating rather than fixed interest rates (i.e., interest rates adjusted about every six months to reflect changes in market rates). At a more general level, this privatization of financial flows allowed private banking institutions to displace TNCs and official aid as the most important source of foreign capital available to third world countries. In the 1960s official aid accounted for 50 percent, foreign direct investment by TNCs for 30 percent, and bank loans and bonds for only 10 percent of the total flow of external financial resources to Latin America; ${ }^{14}$ by the end of the $1970 \mathrm{~s}$, banks and bondholders were responsible for 65 percent of this flow, FDI was just over 15 percent, and official aid stood at only 12 percent (Frieden, 1981: Table 1).

The debt burden grew after the quadrupling of oil prices in 1973, when private banks experienced a sudden increase in loanable funds as the Arab oil revenues (petrodollars) flooded bank coffers. This excess liquidity created pressure on the banks to expand their loan portfolios. With commodity prices generally up at the time, third world nations appeared an attractive place in which to stash the petrodollars, a process called recycling. Most developing countries jumped at this opportunity because they faced mounting deficits from their oil import bills. The crunch for heavy borrowers came as the global recession began to spread. The slump in the center countries hurt third world economic performance in various ways: commodity prices fell, the terms of trade became more adverse, export markets were eroded, and interest rates rose $^{15}$ (a rise in part triggered by the growing budget deficits in the United States). Pretty soon, developing nations were forced to borrow more and more just to meet repayment schedules of old loans. By 1982, many of these countries were in a situation where virtually their entire export revenues were insufficient to service their external public debt (see Table 3). And the banks, who could not afford to have these countries default, have been forced to continue lending. The claims of the nine largest US banks on Mexico, Brazil, and Argentina alone equaled 112 percent of the banks' capital in mid-1982 (Lissakers, 1983: 175; Newsweek, 1983b: 34-35). It is a debt trap from which both sides are finding it difficult to escape.

A lasting solution must go to the heart of the third world debt problem: countries are trying to finance long-term development projects by short-term 
Table 3

Estimated External Debt Service Payments, 1982

(per cent of exports of goods and services)

\begin{tabular}{lrrr}
\hline Country & Total & Interest & Principal $^{1}$ \\
\hline Argentina & 179 & 44 & 135 \\
Mexico & 129 & 37 & 92 \\
Ecuador & 122 & 30 & 92 \\
Brazil & 122 & 45 & 77 \\
Chile & 116 & 40 & 76 \\
Venezuela & 95 & 14 & 81 \\
Colombia & 94 & 25 & 69 \\
Philippines & 91 & 18 & 74 \\
Peru & 90 & 21 & 69 \\
Turkey & 68 & 13 & 55 \\
Korea & 53 & 11 & 43 \\
Thailand & 48 & 10 & 38 \\
Egypt & 48 & 7 & 41 \\
Yugoslavia & 46 & 14 & 32 \\
Algeria & 39 & 12 & 27 \\
Indonesia & 27 & 8 & 19 \\
Taiwan & 21 & 5 & 16 \\
Nigeria & 20 & 7 & 13 \\
Malaysia & 17 & 5 & 12 \\
\hline
\end{tabular}

${ }^{1}$ All debts due within the year, including amortization of medium- and long-term debt plus shortterm debt outstanding at the beginning of the year.

Source: Morgan Guaranty Trust Company, "World Financial Markets," October 1982, p. 5, cited in Lewis (1983: 29).

liabilities. But from what quarter can we expect change to come? It is unlikely that the major third world debtors will voluntarily reduce their borrowing because total export revenues are already inadequate in some cases to service the existing external debt and further cutbacks would force the curtailment of almost all imports and domestic subsidies for essential goods and development programs-a politically unpopular (if not fatal) course of action. The large banks also are reluctant to voluntarily reduce their lending to a sustainable rate because they are vulnerable to the threat of default if they force third world nations to borrow less.

The key actor in managing the international debt crisis is the International Monetary Fund (IMF), which at the behest of the United States is adopting an ever more assertive role. Traditionally, the IMF imposed austerity programs on countries that required emergency loans or needed to reschedule their external debt in order to avoid default. ${ }^{16}$ For the first time, however, the IMF is now applying conditionality to lending banks as well as to borrowing countries (Lissakers, 1983). The IMF loan package for Mexico in 1982, for example, was not approved until the banks had agreed to provide $\$ 5$ billion; this pattern 
was repeated in rescue packages assembled by the IMF for Argentina, Brazil, and Yugoslavia.

The commercial banks, which historically have resisted attempts to intervene in their global operations by their governments and by international agencies, are hailing a new era of cooperation with officialdom. This is not surprising when one realizes that, in effect, the IMF is acting as enforcer of the banks' loan contracts (see Lissakers, 1983: 168-171). Continued access to IMF funds is contingent on the debtor's regular payments on its commercial interest. Both the US Federal Reserve system and the IMF have allowed the banks a free hand in setting the terms for new bank loans and rescheduling. The banks have seized this opportunity to sharply increase the interest margin charged on rescheduled loans and to tack on additional hefty fees which will cost Mexico, to take a well known case, about $\$ 800$ million over the base interest rate in 1983. From the banks' perspective, loans to troubled borrowers like Mexico and Brazil are at present among the most lucrative assets on their books. There also appears to be an implicit US government guarantee for these new loans to uncreditworthy borrowers, although neither banks nor government officials will admit this openly.

The danger for the future is that banks are assuming a larger and larger role in the financing of foreign governments, and eventually the line between the foreign policy interests of the United States (and other center countries) and the commercial interests of private banks will be blurred to the point of nonexistence $^{17}$ (Hulbert, 1982). Because private bankers are virtual newcomers to the politics of collecting debts from third world nations, they have pressured Washington and the IMF to come to their assistance. This worked to Chase Manhattan's good fortune in the case of Iran, for example, where billions of dollars in Iranian loans were wiped off its books after the US government decided to freeze the post-Shah regime's assets in the United States and permit banks to seize those deposits to pay off their Iranian loans. Government officials, on the other hand, will find it tempting to turn to banks as instruments of foreign policy when faced with the prospect of a friendly nation going bankrupt. The third world liquidity crisis of the 1980s has altered, then, not only the way in which banks and governments deal with international debt problems, but more importantly how they deal with each other.

\section{Conclusions}

The growing internationalization of the center countries since 1970 and the decline in the relative economic importance of the United States have contributed to the emergence of a more interdependent world. This interdependence, however, is still fundamentally asymmetrical. The contemporary global crisis may have been aggravated by the policies and problems of the third world nations, but it was not caused or dominated by them. The inflation, unemployment, and economic stagnation that have characterized the international recession are a product of long-run structural trends in the world 
economy and of macroeconomic and even domestic (e.g., federal budgetary) decisions emanating from the center countries. It is instructive and maybe ironic that the world's two most populous nations, China and India, have up to now escaped serious slowdowns in growth because their economies are more self-sufficient than most others and therefore less vulnerable to events in the industrialized world.

The solution to the global crisis will not come from a dismantling of the international economy or a generalized movement toward greater autarky, however. Paradoxically, perhaps, the returns to most third world countries would probably be improved by a more genuinely open international system. The success of the most rapidly growing of the developing nations (the socalled semiperiphery), for example, has been predicated on open access to core country markets, especially for their manufactured exports; substantial imports of intermediate and capital goods from the center countries have been an important element of their growth strategies as well. The effects of the world recession are beginning to alter this pattern. The acute financial crises that have erupted like brush fires across the third world recently have led a number of governments to devalue their currencies and cut imports. Some center countries, who claim that imports of manufactures from the third world have contributed to their economic declines, are consciously moving in the direction of discriminatory policies that aim to co-opt or tame a handful of the most advanced developing nations. This approach will not yield the intended result of a more productive and dynamic manufacturing sector in the centers, although it is easy to see why organized labor prefers the minimal but predictable gains to be had from protectionism. Industrial policy in the developed countries would be more effective if it promoted positive structural adjustments that would help absorb the workers displaced from traditional manufacturing jobs. This means recognizing and adapting to changes in the industrial capacity and export potential of third world nations.

\section{NOTES}

1 The secondary recovery of antimony, for example, yields a larger supply than imports of the metal itself. The oil price rises of the 1970 s made high-cost methods for recovering oil from abundant coal shale and viscous deposits economically feasible for the first time, and in addition sparked new developments in solar energy technology. In an even more dramatic breakthrough, fiber optics now make it possible to substitute glass filaments for the copper in cables and wires, thus shrinking world demand for a metal whose extraction is overwhelmingly concentrated in four underdeveloped countries (Zambia, Chile, Peru, and Zaire).

2 The share of related-party transfers varied from 45 percent for United States companies, to 30 percent for TNCs based in Western Europe, and to 17 percent for Japanese firms.

3 Nemeth's and Smith's (1983) results suggest a hierarchical ordering of nations into a core, a periphery, and two distinct intermediate semiperipheries. Of the 86 countries for which appropriate data were available, there were nine in the core (Belgium, Canada, France, Italy, Japan, Netherlands, United Kingdom, United States, West Germany), sixteen in the "strong" semiperiphery (Argentina, Australia, Austria, Brazil, Denmark, Hong Kong, India, Mexico, Nigeria, Philippines, Singapore, South Korea, Spain, Sweden, Switzerland, 
Venezuela), twelve in the "weak" semiperiphery (Chile, Colombia, Egypt, Ghana, Kenya, Malaysia, New Zealand, Pakistan, Portugal, Thailand, Zaire, Zambia), and the remainder are in the periphery. In network analysis, two actors are structurally equivalent if they relate to all other actors in the system in the same manner.

4 During 1981 food prices fell 21 percent, agricultural raw materials 13 percent, and minerals 12 percent. Most commodity prices continued to fall in 1982 (Riding, 1982).

5 The third world received $\$ 47$ billion in new bank loans in 1981 ; the following year the loans shrank to $\$ 19.7$ billion and they were expected to shrink even more in 1983 (Newsweek, 1983b: 35).

6 Certain industries have been particularly hard hit. In 1979 imports represented 51 percent of US domestic consumption in consumer electronics products, 46 percent in textiles, 37 percent in footwear, 26 percent in machine tools, 21 percent in cars, and 90 percent in cutlery (Magaziner and Reich, 1982: 33).

7 Plant, equipment, and capital goods now account for 43 percent of Japanese exports.

8 The large Latin American economies (Brazil, Mexico, and Argentina) produced 12 percent of total manufactured exports from the third world in 1979, and the large South Asian economies (India and Pakistan) accounted for 6 percent.

9 The Swiss government avoided any serious unemployment in the late 1940 s by simply halving its foreign work force, from 140,000 in 1947 to 75,000 in 1950 . More recently, about 250,000 foreign workers were eliminated from the Swiss labor pool between 1973 and 1976 through return migration, a ban on further hiring, and the expiration of contracts (Katzenstein, 1980: 519).

10 Foreign direct investment refers to the acquisition or control of productive facilities outside the home country. Control is generally thought to mean at least a 25 percent participation in the share capital of the foreign enterprise, although the published U.S. Department of Commerce data are based on equity holdings as low as 10 percent.

11 In contrast, US manufacturing investment in Asian countries is frequently concentrated in a single industrial group. Electrical and electronic equipment, for example, represents about 8 percent of US manufacturing FDI worldwide, whereas it is 67 percent of the US manufacturing total in Malaysia, 58 percent in Singapore, and 34 percent in Taiwan (U.S. Department of Commerce, 1982: Table 14).

12 Clearly Mexico's large oil and natural gas supplies are a potent trade weapon that in times of oil scarcity can significantly increase Mexico's leverage in its bilateral relations with the United States (and other oil-importing countries as well). Unfortunately for Mexico, oil prices have fallen in recent years and after Mexico's financial crisis in August of 1982 the United States demanded-and got-a 110,000 barrel-a-day increase in high-grade Mexican oil imports to the US in exchange for a $\$ 1$ billion emergency loan from Washington. These added oil imports have been pumped into the United States' strategic oil reserves in order to minimize US vulnerability in the event of a future oil shortage.

13 Even this latter amount is understated since it does not include debt outstanding for less than one year.

14 The remaining 10 percent came from private voluntary organizations and other suppliers.

15 Every 1 percent rise in interest rates costs Mexico an additional $\$ 500$ million per year (Riding, 1982).

16 A recent case is Venezuela which has been hit hard by recent declines in the price of oil and is seeking to reschedule $\$ 16.3$ billion in obligations to more than 450 foreign creditors that will fall due by the end of 1984 . Two-thirds of the debt Venezuela is seeking to reschedule is in short-term obligations (24 months or less). IMF's austerity plan, which Venezuela is resisting, would force the country to unify its three-tier exchange rate, eliminate subsidies on gasoline and foodstuffs, cut public spending, and keep interest and discount rates high (Kinzer, 1983).

17 That banking interests and national interests $d o$ differ is illustrated by the case of Poland. Unlike most observers, bankers were not particularly concerned that the Soviet Union might intervene militarily when labor riots spread across Poland in the summer of 1980 . 
With Poland in danger of defaulting on its large external debt, one banker said a Soviet takeover could be beneficial because Poland's credit rating would then go up. Another banker commented, "Who knows which political system works? The only thing we care about is: can they pay their bills?"' (Hulbert, 1982: 365).

BALDWIN, David A.

\section{REFERENCES}

1980 "Interdependence and power: a conceptual analysis." International Organization 34, 4 (Autumn): 471-506.

BRANDT, Willy et al.

1980 North-South: A Program for Survival. Cambridge, Mass.: M.I.T. Press.

Business Week

1980 "The decline of U.S. industry." June 30, pp. 58-65.

Cовв, William B.

1981 "Tourism as a positive factor in the Mexican economy and in Mexican foreign relations." Pp. 178-191 in Robert H. McBride (ed.), Mexico and the United States. Englewood Cliffs, N.J.: Prentice-Hall.

Committee for Economic Development

1983 Productivity Policy: Key to the Nation's Economic Future. New York: Committee for Economic Development.

Cornelius, Wayne A.

1981 "Immigration, Mexican development policy, and the future of U.S.-Mexican relations." Pp. 104-127 in Robert H. McBride (ed.), Mexico and the United States. Englewood Cliffs, N.J.: Prentice-Hall.

Evans, Peter B.

1979 "Beyond center and periphery: a comment on the contribution of the world system approach to the study of development." Sociological Inquiry 49, 4: 15-20.

1982 "The changing international position of U.S. manufacturing and U.S. industrial policy: implications for Latin American industrialization." A preliminary progress report submitted to UNIDO, Country and Regional Studies Branch, Vienna, Austria. October 20. Mimeograph. 37 pp.

Fishlow, Albert, Jean Carrière and Sueo Sekiguchi

1981 Trade in Manufactured Products with Developing Countries: Reinforcing North-South Partnership. A Report to the Trilateral Commission (Triangle Papers, No. 21). New York:

Frieden, Jeff The Trilateral Commission.

1981 "Third world indebted industrialization: international finance and state capitalism in Mexico, Brazil, Algeria, and South Korea." International Organization 35, 3 (Summer): 407-431.

Fröbel, Folker, Jürgen Heinrichs and Otto Kreye

1978 "The new international division of labor." Social Science Information 17, 1: 123-142.

Gall, Norman

1983 “Black ships are coming?" Forbes (January 31): 67-75.

Gerefri, Gary

1983 The Pharmaceutical Industry and Dependency in the Third World. Princeton, N.J.: Princeton University Press.

Gerefri, Gary and Peter B. Evans

1981 "Transnational corporations, dependent development, and state policy in the semiperiphery: a comparison of Brazil and Mexico." Latin American Research Review $16,3: 31-64$.

Helleiner, Gerald

1981 Intra-firm Trade and the Developing Countries. New York: St. Martin's Press.

HULBert, Mark

1982 "Will the U.S. bail out the bankers?" The Nation (October 16): 364-366. 
INKELES, Alex

1975 "The emerging social structure of the world." World Politics 27, 4 (July): 467-495.

Inter-American Dialogue

1983 The Americas at a Crossroads. Washington, D.C.: Woodrow Wilson International Center for Scholars.

Katzenstein, Peter J.

1980 "Capitalism in one country? Switzerland in the international economy." International Organization 34, 4 (Autumn): 507-540.

KINZER, Stephen

1983 "Venezuela resisting I.M.F. rein." New York Times, July 25, pp. 1, 25.

Lewis, John P.

1983 "Can we escape the path of mutual injury?" Pp. 7-48 in John P. Lewis and Valeriana Kallab (eds.), U.S. Foreign Policy and the Third World: Agenda 1983. New

LisSAKERs, Karin York: Praeger (published for the Overseas Development Council).

1983 "Dateline Wall Street: faustian finance." Foreign Policy, 51 (Summer): 160-175.

LOHR, Steve

1982 “4 'New Japans' mounting industrial challenge." New York Times, August 24, pp. A1, D5.

Magaziner, Ira C. and Robert B. Reich

1982 Minding America's Business: The Decline and Rise of the American Economy. New York: Harcourt Brace Jovanovich.

MOORE, Wilbert E.

1966 "Global sociology: the world as a singular system." American Journal of Sociology 71, 5 (March): 475-482.

MuÑoz, Heraldo

1981 "The strategic dependency of the centers and the economic importance of the Latin American periphery." Latin American Research Review 16, 3: 3-29.

Nemeth, Roger J. and David A. Smith

1983 "International trade and world system structure: a multiple network analysis." Forthcoming in Review.

Newsweek

1980 "A new LDC debt crunch." May 26, pp. 74-75.

1983a "A rising tide of protectionism." May 30, pp. 26-33.

$1983 \mathrm{~b}$ “"The dynamite issue." May 30, pp. 34-36.

New York Times

1983 “Debts owed by 7 nations." July 25, p. 25.

RANDALL, Laura R.

1981 "Mexican development and its effects upon United States trade." Pp. 49-76 in Robert H. McBride (ed.), Mexico and the United States. Englewood Cliffs, N.J.: Prentice-Hall.

Riding, Alan

1982 "Economic frustration grips many developing countries." New York Times, December 6, pp. 1, 32 .

United Nations Centre on Transnational Corporations (UNCTC)

1983 Transnational Corporations in World Development: Third Survey. New York: UNCTC. (United Nations publication, Sales No. E.83.II.A.14).

U.S. Department of Commerce

1982 "U.S. direct investment abroad in 1981" (Obie G. Whichard). Survey of Current Business 62, 8 (August): 11-29.

WACHTEL, Howard M.

1977 The New Gnomes: Multinational Banks in the Third World, Washington, D.C.: Transnational Institute. 
WALLERSTEIN, Immanuel

1974 The Modern World-System: Capitalist Agriculture and the Origins of the European WorldEconomy in the Sixteenth Century. New York: Academic Press.

1979 The Capitalist World-Economy. New York: Cambridge University Press.

WaLTz, Kenneth N.

1970 "'The myth of national interdependence." Pp. 205-223 in Charles P. Kindleberger (ed.), The International Corporation. Cambridge, Mass.: M.I.T. Press. 